\title{
Expression of immune-related gene from African mud catfish Clarias gariepinus reared in bioflocs systems after Aeromonas hydrophilia infection
}

\section{Omoniyi Michael Popoola ${ }^{1,2 *}(\mathbb{D})$, Ayomide Miracle Oyelade ${ }^{1}$, Success Taiwo Torhukerijho' ${ }^{1} \mathbb{D}$}

${ }^{1}$ Department of Fisheries and Aquaculture, Federal University of Technology, PMB 704 Akure, Nigeria.

${ }^{2}$ Aquatic Environmental Biotechnology \& Nanotechnology Division ICAR-Central Inland Fisheries Research Institute, Indian Council of Agricultural Research, Barrackpore, Kolkata-700 120 West Bengal, India.

\section{How to cite}

Popoola, O. M., Oyelade, A. M., \& Torhukerijho, S. T. (2021). Expression of immune-related gene from African mud catfish Clarias gariepinus reared in bioflocs systems after Aeromonas hydrophilia infection. Biotech Studies, 31(1), 1727. https://doi.org/10.38042/biotechstudies.1073521

\section{Article History}

Received 29 December 2021

Accepted 08 February 2022

First Online 14 February 2022

\section{Corresponding Author}

Tel.: +234 8038349325

E-mail: ompopoola@futa.edu.ng

\section{Keywords}

Immune gene

Haematology

Bioflocs

Clarias gariepinus

Carbon nitrogen ratio

\begin{abstract}
The influence of various carbon sources as bioflocs on relative immunological gene expression, haematology, growth, and microbial community in Clarias gariepinus juvenile culture is investigated in this study. The bioflocs groups (four) were created by daily supplementation with four carbon sources (cassava peel, tapioca, wheat offal, and brewery waste) with a carbon-nitrogen ratio of 20 and the control without carbon addition. The juvenile Clarias gariepinus $(8.16 \pm 0.2 \mathrm{~g}$ ) was stocked into each bioflocs system and reared for 72 days. The results revealed that the water quality parameter and survival rate differed significantly across the treatments. The microbial community revealed that there were differences in bacterial intensity and diversity among the various culture systems. The haematological parameters between the treatments showed a significant difference $p<0.05$ in the challenged test. qRT-PCR was used to assess immune-related gene expression, and four immune genes (IL-10, TNF- $\alpha$, TGF- $B$, $I L-16)$ were shown to be increased. As a result, the bioflocs system can be considered to boost innate immunity and immune-related gene expression. Overall, this research found that using bioflocs technology can help with immunostimulation, and that the effect is independent of the organic carbon utilised to keep the fish alive.
\end{abstract}

\section{Introduction}

An ecologically important and commercially valued fish for sub-Sahara Africa especially Nigerian aquaculture industry is the African catfish, Clarias gariepinus, belonging to the family Claridae (Ita, 1980). Clarias gariepinus is generally and widely cultivated in ponds because of their ability to survive in captivity, they also occur freely in natural freshwaters in Nigeria (Adebayo \& Daramola, 2013). The current demand for fish protein has led to the intensification of aquaculture to make fish available to the growing population, therefore, increasing productivity per unit space is accomplished by increasing the stocking density of fish. Due to limited control over pathogens, health protection and biosecurity are major challenges to production intensification (Xie \& Yu, 2007). Attaining sustainability in feed management is also an important aspect of the production intensification of any aquatic organism.

The scientific community's understanding of the genus Aeromonas has also evolved. Initially, aeromonads were only recognised as producing systemic disorders in poikilothermic animals. The genus Aeromonas is now recognised not only as a significant disease-causing pathogen of fish and other coldblooded animals, but also as the causative agent for a variety of infectious problems in both immunocompetent and immunocompromised people (Janda \& Abbott, 2010). Mesophilic species (A. 
hydrophila and $A$. veronii) infect fish with a similar range of diseases, including motile Aeromonas septicemia (hemorrhagic septicemia) in carp, tilapia, perch, catfish, and salmon, and a red sore disease in carp, tilapia, perch, catfish, and salmon, and ulcerative infections in catfish, cod, carp, and goby (Joseph \& Carnahan, 1994; Ture et al., 2018). Over the last decade, mesophilic Aeromonas species, most notably $A$. hydrophila, have been connected to massive die-offs and fish kills all over the world, resulting in enormous economic losses. $A$. hydrophila is a pathogenic bacterium that is found all over the world, especially in warm water. They are gram-negative, motile rods with oxidase and catalase activity, as well as fermentative (Sabur, 2006). MAS is caused by the bacterium $A$. hydrophila (motile Aeromonas septicemia). This disease affects both farmed and wild fish, however fish in intensive culture systems are more sensitive to the disease condition caused by $A$. hydrophila.

Bioflocs technology is a method of improving water quality by adding extra carbon to the aquaculture system, either from an external source or by increasing the carbon content of the feed. This approach encourages bacterial growth to take up nitrogen, resulting in a faster decrease in ammonium content than nitrification (Hargreaves, 2006). This biotechnological approach has proved efficient in improving water quality and feed usage efficiency compared to conventional practices for farming of Tilapia and Litopenaeus vannamei (Avnimelech, 1999; Milstein et al., 2001). The bioflocs rearing system has been developed to implement the use of minimum water exchange and usage in aquaculture ponds, through maintaining adequate water quality within the culture unit as well as producing heterotrophic media and a multiphasic feed source that can serve as food for aquatic organisms (Avnimelech, 1999; Crab et al., 2007; Crab, 2010), invented the bioflocs rearing system to execute minimum water exchange and water utilisation in aquaculture ponds, which improves aquatic creatures' nutritional and reproductive performance (Emerenciano et al., 2013). It has been hypothesised that biofouling could be reduced as a result of the minimum water exchange.

Bioflocs keeps pathogens out of ponds and disease outbreaks from spreading between farms ( $\mathrm{Crab}$ et al., 2010). Recent studies have evaluated probiotic effects of bioflocs and role in immune response mechanisms in an attempt to demonstrate its benefits to aquatic organisms' health (Wang et al., 2013; Ahmad et al., 2016), suggesting that disease can be prevented in fish using this sustainable rearing system (Wang et al., 2013; Ahmad et al., 2016; Liu et al., 2016). In terms of conferring immunological benefits, $\mathrm{C} / \mathrm{N}$ ratios in bioflocs improved the innate immune response and antioxidant status in various species of shell and finfishes when challenged with a disease-causing organism (bacteria) (Xu \& Pan, 2013; Ekasari et al., 2014; Ahmad et al., 2016), implying that disease can be prevented in fish using this sustainable rearing system. The study aimed at determining how different carbon sources used in bioflocs affect immunological parameters and immunerelated gene expression in the $C$. gariepinus challenged with A. hydrophilia.

\section{Materials and Methods}

\section{Experimental design}

Approximately 1000 Clarias gariepinus Juvenile (Initial weight $8.21 \pm 0.3 \mathrm{~g}$ ) was obtained from the Department of Fisheries and Aquaculture Technology Teaching and Research Farm, the Federal University of Technology Akure and acclimated in a water volume of 100L. Acclimation to experimental conditions was carried for 14 days within the facilities of the institution, and during this period, the juveniles were fed with a commercial diet two times daily (08.00 and $18.00 \mathrm{~h}$ ) at $3 \%$ of their body weight.

T1 (Clearwater), T2 (Cassava peel as a carbon source), T3 (Tapioca as a carbon source), T4 (Wheat offal as a carbon source), T5 (Brewery waste as a carbon source) were the five treatment groups, four bioflocs treatments, and one control in triplicate with a water volume of $500 \mathrm{~L}$. Collecting Pond bottom soil from a reputed fish farm was used to make the inoculum. In glass tanks (5L), inoculum was made by mixing $20 \mathrm{~g}$ of pond bottom soil with $1 \mathrm{~L}$ of well-aerated water containing $10 \mathrm{mg} \mathrm{L}^{-1}$ ammonium sulphate $(\mathrm{NH})_{4} \mathrm{SO}_{4}$ and $400 \mathrm{mg} \mathrm{L}^{-1}$ of various carbon sources (tapioca, wheat offal, brewery, and cassava peel). For $24 \mathrm{~h}$, the suspension was incubated for the development of microbial growth.

The prepared inoculum was added to the respective experimental groups after floc formation, the tank was aerated for 7 days to ensure optimum floc formation, and carbon sources were added at a rate of $20 \mathrm{~g}$ of carbon source per $1 \mathrm{~g}$ of TAN as described by (Avnimelech, 1999) who assumed that $20 \mathrm{~g}$ of carbon source is required to convert $1 \mathrm{~g}$ of TAN, and (Ebeling et al., 2006) to provide an initial substrate and stimulate the growth of all the treatment groups, 100 fish per tank $\left(2 \times 1 \times 1 \mathrm{~m}^{3}\right)$ were stocked. Every week, $70 \%$ of the water in the control group was replaced with fresh water, whereas there was no water exchange in the bioflocs based groups. Evaporation losses were corrected with dechlorinated fluids to account for the bioflocs' variation and achieve optimal experimental conditions. The experimental fish were fed with commercial diets at $3 \%$ of their body weight under continuous aeration using air blower installed at 10 lines (5 l/min per line).

The determination of the required amount of carbon to reduce the total ammoniacal nitrogen was calculated as follows:

Calculation 1: (Carbon Nitrogen (C: N) content in the feed)

$C: \frac{\text { Kg of feed } \times 0.9(90 \% \text { dry matter }) \times 0.7(30 \% \text { of fish assimilation }}{2 \text { (Carbon content of the feed } ~ 50 \% \text { based on dry matter }}$ 
$N: \frac{\text { Kg of feed } \times 0.9(90 \% \text { dry matter }) \times 0.7(30 \% \text { of fish assimilation } \times \text { Crude protein of feed }(\%)}{6.25(\text { constant })}$ Calculation 2: (Adjusting the Carbon Nitrogen Ratio (C: N) $C: N$ of $20: 1=(N($ Nitrogen content in feed $) \times 20)-C($ Carbon content in feed $) \times 2$

\section{Haematological indices}

Blood samples were obtained by caudal veinpuncture using a syringe and dispensed into a sample bottle containing ethylene diamine tetra-acetic $(5 \mathrm{~mL}$ EDTA) as an anticoagulant after five experimental fish were taken from each experimental tank and sedated with clove oil ( $\left.50 \mathrm{mg} \mathrm{L}^{-1}\right)$.

Svobodova et al. (1991) described a method for analysing blood parameters (RBC, HB, WBC, PCV, MCV, $\mathrm{MCHC}$, and $\mathrm{MCH})$. The haematocrit $(\mathrm{Ht})$ was evaluated using the microcentrifuge technique, and the white blood cell (WBC) and red blood cell (RBC) were determined using a haemocytometer. The $\mathrm{Ht}, \mathrm{HB}$, and $\mathrm{RBC}$ values were used to determine the $\mathrm{MCV}, \mathrm{MCH}$, and MCHC.

\section{Microbial community analysis}

The APHA (1998) approach was used to characterise the bioflocs and hindgut bacterial populations of the experimental fish under each treatment. $1 \mathrm{~mL}$ of the sample was transferred into $9 \mathrm{~mL}$ of sterile distilled water in a bottle at the end of the experiment to obtain dilutions $10^{-1}$, and $1 \mathrm{~mL}$ from the previous dilution was transferred into another $9 \mathrm{~mL}$ of sterile distilled water to obtain dilutions $10^{-2}$ and up to $10^{-5}$, respectively, using a sterile pipette. After that, $1 \mathrm{~mL}$ of each sample from dilutions, $10^{-4}$ and $10^{-5}$ was put into sterile Petri-dishes. Each plate was then filled with $20 \mathrm{~mL}$ of molten sterile nutritional agar that had been cooled to $45^{\circ} \mathrm{C}$. After gently swirling the plates and allowing them to harden, they were incubated at $37^{\circ} \mathrm{C}$ for $24 \mathrm{~h}$. The plates were checked for growing colonies after $24 \mathrm{~h}$. The colonies were counted and their morphological features were recorded. Representative colonies were chosen and sub-cultured on new nutrient agar multiple times until pure cultures were produced. The bacteria were identified using morphological characteristics of the colonies and biochemical assays was performed on each isolate. To establish pure cultures for identification of fungi, representative colonies were chosen and subcultured onto fresh potato dextrose agar. Fungal taxonomic identification was used to identify isolates. The hyphae of the fungal isolates were mounted aseptically on a microscopic slide and given a drop of lactophenol cotton blue before being covered with a coverslip. The slide was examined under the microscope with an x40 objective lens.

\section{Challenge test}

The experimental fish in different bioflocs system were exposed to pathogenic strain of $A$. hydrophilia (MPSTR 2143), mildly pathogenic strain (Animal care Laboratory Ogere), grown on a brain heart infusion broth (EM Science, Darmstadt Germany) in a shaking bath $27{ }^{\circ} \mathrm{C}$ overnight in the Department of microbiology Federal University of Technology, Akure. The concentration of bacterial suspension was determined by the serial plate count method and diluted to $9.3 \times 10^{5}$ CFU. Prior to challenge test, lethal dose ( $\left.\operatorname{LD}_{50-96 h}\right)$ of $A$. hydrophilia (MPSTR 2143) against $C$. gariepinus was determined. Fifteen individuals of $C$. gariepinus were distributed in four tanks in duplicate (120 fish) and maintained without feed till $96 \mathrm{~h}$. The fishes were injected intraperitoneally with $1 \mathrm{~mL}$ of $A$. hydrophilia (MPSTR 2143) suspension with the concentrations: $1 \times$ $10^{9} \mathrm{CFUmL}^{-1}, 1 \times 10^{8} \mathrm{CFUmL}^{-1}, 1 \times 10^{7} \mathrm{CFU} / \mathrm{mL}$ and 0 $\mathrm{CFUmL}^{-1}$ (control, using $500 \mu \mathrm{L}$ of physiological solution $0.9 \% \mathrm{NaCl}$ ). The percentage of mortality was calculated at $24 \mathrm{~h}, 48 \mathrm{~h}, 72 \mathrm{~h}$, and $96 \mathrm{~h}$, respectively as described by Abbott (1925) and the $L_{50}$ was determined with Probit analysis. For the challenge test, fifty fish were challenged by $A$. hydrophila (10 fish/ group) by intraperitoneal injection of $0.5 \mathrm{~mL}$ of bacterial suspension using $2 \mathrm{ml}$ Insulin syringe at a concentration of $1.7 \times 10^{9}$ $\mathrm{CFUmL}^{-1}$ of bacterial culture/fish for $A$. hydrophila obtained from lethal dose $\left(\mathrm{LD}_{50-96 h}\right)$. Injected fish were observed for up to 14 days for daily monitoring of symptoms. Mortality and survival were monitored and recorded. Survival at the end of 14 days post-infection was calculated using the following formula (Amend, 1981).

Relative percentage survival (RPS) $=\frac{\text { Number of surviving fishes after challenge }}{\text { Number of fish bathed with bacteria }} \times 100$

\section{Tissue sampling}

After 14 days of being challenged with $A$. hydrophila, liver samples were taken from the various treatments by slicing the fish to reveal the visceral organs. About $50 \mathrm{mg}$ of liver was sliced off and placed in $1.5 \mathrm{~mL}$ microcentrifuge tubes, which were kept on ice to prevent RNA denaturation owing to temperature changes. The collected materials were transported to the lab, fixed in RNA, and kept at $-20{ }^{\circ} \mathrm{C}$ until RNA extraction was completed.

\section{RNA extraction}

Total RNA was isolated from liver tissue of $A$. hydrophila treated and control C. gariepinus using Trizol reagent. The purity and quantity of isolated total RNA was quantified using Nanodrop ${ }^{\mathrm{TM}}$ Thermo Scientific at the 260:280 ratio. After, the extracted RNA was kept at $-20{ }^{\circ} \mathrm{C}$ till further use.

\section{cDNA synthesis and quantitative Real Time-PCR}

Subsequently, complementary DNA (cDNA) was produced according to the manufacturer's procedure using a cDNA synthesis kit (Bio-iScript Rad's cDNA synthesis kit). With B-actin and Glyceraldehyde-3phosphate dehydrogenase (GAPDH) as a housekeeping gene, specific primers for gene expression were 
constructed to amplify the targeted genes. The qRT-PCR analysis was performed using the Bio-Rad CFX96 Touch Real time PCR detection equipment and Sso Advanced Universal SYBR green supermix (Bio-Rad) according to the manufacturer's instructions and modified by PlazaDiaz et al. (2014) technique.

\section{Data and statistical analysis}

For all genes and samples, the Ct was calculated. The comparative $\mathrm{Ct}$ method was used to calculate the relative quantitation of $T N F-\alpha, I L-16, I L-10$, and TGF- $B$. The target gene's relative quantification value was standardised to an endogenous control and expressed as 2-Ct relative to the calibrator. $\mathrm{Ct}$ is equal to the $\mathrm{Ct}$ of the target gene (TNF- $\alpha, I L-16, I L-10$, and TGF- $B$ ) minus the $\mathrm{Ct}$ of the endogenous control gene (GAPDH and $B$ actin) in this investigation. $\mathrm{Ct}$ is equal to the sample's $\mathrm{Ct}$ minus the calibrator's $\mathrm{Ct}$. The fold change in expression levels was computed by dividing the treated sample's relative gene expression value by the negative control's relative gene expression value. Statistical analyses were performed with one-way analysis of variance (ANOVA) and Dunnett's test to compare differences between the treatment groups and the negative control group, and the data were tested for normality and heterogeneity of variance using the Kolmogorov-Smirnov test and Levene's test, respectively. Multiple comparisons were taken into account when calculating the p-values. Graphpad Prism version 8.0 was used to visualise the results.

All data were subjected to an analysis of variance (ANOVA) with a significance level of 0.05 (95\% confidence), and the findings were given as Mean SE. To look for significant changes between the treatments, Duncan's multiple range tests were utilised. IBM SPSS statistics version 22 for Windows was used to conduct all of the analyses. Prior to statistical analysis, Log 2 Transformation was performed.

\section{Results}

The growth performance of Clarias gariepinus showed no significant difference $(p<0.05)$ in the weight gain, FCR and SGR (Table 1), although a significant difference $p<0.05$ was observed in the relative survival recorded in tapioca-based treatment $76.00 \pm 1.50$ and lowest in control 50 \pm 10.00 (Figure 1).

The haematological parameters (PCV, HB, RBC, $\mathrm{WBC}, \mathrm{MCH}, \mathrm{MCV}$, and $\mathrm{MCHC}$ ) of Clarias gariepinus raised in bioflocs systems before and after challenge with $A$. hydrophilia is shown in Table 2 . The haematological parameters were significantly different $p<0.05$ but tapioca was observed to be the lowest compared to the control and other bioflocs systems. WBC showed no significant difference among the treatments group.

The haematological parameters (PCV, HB, RBC, WBC, $\mathrm{MCH}, \mathrm{MCV}$, and $\mathrm{MCHC}$ ) of Clarias gariepinus raised in bioflocs systems before and after challenge with $A$. hydrophilia is shown in Table 2 . The haematological parameters were significantly different $p<0.05$ but tapioca was observed to be the lowest compared to the control and other bioflocs systems. WBC showed no significant difference among the treatments group.

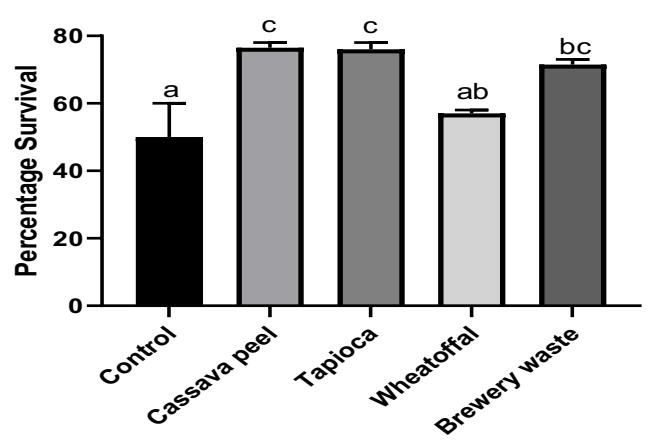

Figure 1. Relative percentage survival of $C$. gariepinus in different treatment groups.

The haematological parameters (PCV, HB, RBC, $\mathrm{WBC}, \mathrm{MCH}, \mathrm{MCV}$, and $\mathrm{MCHC}$ ) of Clarias gariepinus raised in bioflocs systems before and after challenge with $A$. hydrophilia is shown in Table 2 . The haematological parameters were significantly different $p<0.05$ but tapioca was observed to be the lowest compared to the control and other bioflocs systems. WBC showed no significant difference among the treatments group.

Gram-negative bacilli bacterial colonies from the Enterobacteriaceae family were detected, including Proteus sp., Klebsiella sp., Shigella sp., and Escherichia coli (Table 3). A group of sporulated gram-positive bacilli linked to lactobacillus and bacteria that are functionally referred to as cocci has been discovered. The presence or absence of the indicated bacterium species in the culture media, as well as heterotrophic bacteria, was a common occurrence.

Colonies from the family Hypocreaceae, which included Trichoderma sp., the family Trichomaceae, which included colonies from Aspergillus sp. and

Table 1. Growth performance of $C$. gariepinus juveniles raised in bioflocs systems

\begin{tabular}{llllll}
\hline Treatments & Control & Cassava peel & Tapioca & Wheat offal & Brewery waste \\
\hline Initial $(\mathrm{g})$ & $8.13 \pm 0.48$ & $8.07 \pm 0.56$ & $8.18 \pm 0.25$ & $8.61 \pm 0.01$ & $8.62 \pm 0.07$ \\
Final $(\mathrm{g})$ & $88.45 \pm 5.45$ & $81.30 \pm 2.20$ & $90.35 \pm 3.25$ & $81.70 \pm 22.16$ & $77.10 \pm 2.20$ \\
Weight gain $(\mathrm{g})$ & $80.31 \pm 5.93$ & $73.23 \pm 2.76$ & $82.16 \pm 3.50$ & $73.08 \pm 22.09$ & $68.47 \pm 2.14$ \\
SGR & $2.98 \pm 0.15$ & $2.89 \pm 0.12$ & $3.00 \pm 0.08$ & $2.76 \pm 0.35$ & $2.74 \pm 0.03$ \\
FCR & $0.66 \pm 0.05$ & $0.72 \pm 0.03$ & $0.64 \pm 0.03$ & $0.79 \pm 0.24$ & $0.77 \pm 0.02$ \\
\hline
\end{tabular}

SGR: Specific growth rate, FCR: Feed conversion ratio 
Table 2. Haematological Parameters of $C$. gariepinus raised in bioflocs systems

\begin{tabular}{|c|c|c|c|c|c|c|}
\hline & Treatment & Control & Cassava peel & Tapioca & Wheat offal & Brewery waste \\
\hline \multirow{2}{*}{$\mathrm{HB}(\mathrm{g} / 100 \mathrm{ml})$} & Pre challenge & $11.00 \pm 0.30^{b}$ & $9.80 \pm 0.50^{\mathrm{ab}}$ & $9.55 \pm 0.15^{a}$ & $10.20 \pm 0.20^{\mathrm{ab}}$ & $10.20 \pm 0.50^{\mathrm{ab}}$ \\
\hline & Post challenge & $12.40 \pm 0.30^{b}$ & $10.65 \pm 0.65^{a}$ & $11.20 \pm 0.50^{\mathrm{ab}}$ & $11.15 \pm 0.15^{a b}$ & $10.15 \pm 0.15^{\mathrm{a}}$ \\
\hline \multirow{2}{*}{$\mathrm{Ht}(\%)$} & Pre challenge & $33.00 \pm 1.00^{\mathrm{b}}$ & $29.50 \pm 1.5^{\mathrm{ab}}$ & $28.50 \pm 0.50^{a}$ & $30.50 \pm 0.50^{\mathrm{ab}}$ & $30.50 \pm 1.50^{\mathrm{ab}}$ \\
\hline & Post challenge & $37.00 \pm 1.00^{\mathrm{b}}$ & $32.00 \pm 2.00^{a}$ & $33.50 \pm 1.50^{a b}$ & $33.50 \pm 0.50^{\mathrm{ab}}$ & $30.50 \pm 0.50^{a}$ \\
\hline \multirow{2}{*}{$\begin{array}{l}\text { WBC } \\
(x 103 / \mathrm{mm} 3)\end{array}$} & Pre challenge & $5250 \pm 450.00^{a}$ & $5850 \pm 450.00^{a}$ & $6800 \pm 300.00^{a}$ & $5150 \pm 650.00^{a}$ & $5325 \pm 725.00^{a}$ \\
\hline & Post challenge & $4500.00 \pm 300.00^{a}$ & $5725.00 \pm 325.00^{a}$ & $5100.00 \pm 700.00^{a}$ & $4750.00 \pm 250.00^{a}$ & $6250.00 \pm 950.00^{a}$ \\
\hline \multirow{2}{*}{$\mathrm{RBC}$} & Pre challenge & $3.68 \pm 0.13^{b}$ & $3.25 \pm 0.15^{\mathrm{ab}}$ & $3.15 \pm 0.05^{\mathrm{a}}$ & $3.35 \pm 0.05^{a b}$ & $3.38 \pm 0.18^{a b}$ \\
\hline & Post challenge & $4.1 \pm 0.10^{b}$ & $3.53 \pm 0.23^{a}$ & $3.73 \pm 0.18^{\mathrm{ab}}$ & $3.73 \pm 0.08^{a b}$ & $3.35 \pm 0.05^{\mathrm{a}}$ \\
\hline
\end{tabular}

Values are expressed as mean \pm SE. The mean values $(n=2)$ with different superscripts within the same row are significantly different ( $p<0.05)$. HB: haemoglobin, Ht: haematocrit, RBC: red blood cell, WBC: white blood cell

Penicillum chysogenum were among the groups detected (Table 4). A group of filamentous fungi was discovered, including Fusarium sp. colonies and the saprophytic fungus Rhizopus sp. The identification of fungus species and their qualitative characterization to their presence or absence in the culture media was noticed.

Table 3. Characterization of bacteria isolate in biofloc systems

\begin{tabular}{|c|c|c|c|c|c|}
\hline Treatment & Control & $\begin{array}{l}\text { Cassava } \\
\text { peel }\end{array}$ & Tapioca & $\begin{array}{l}\text { Wheat } \\
\text { offal }\end{array}$ & $\begin{array}{l}\text { Brewery } \\
\text { waste }\end{array}$ \\
\hline Bacillus sp. & - & + & + & + & + \\
\hline Shigella sp. & + & + & - & - & - \\
\hline Proteus sp. & - & + & + & + & - \\
\hline Escherichia coli & + & - & + & - & + \\
\hline $\begin{array}{l}\text { Staphylococcus } \\
\text { epidermidis }\end{array}$ & + & - & - & + & - \\
\hline $\begin{array}{l}\text { Staphylococcus } \\
\text { aureus }\end{array}$ & + & - & - & + & + \\
\hline Klebsiella sp. & + & - & - & - & + \\
\hline
\end{tabular}

Changes in the expression of all immunological genes investigated as a result of $A$. hydrophilla infection compared to the calibrator sample (Control). When standardised against GAPDH, the expression levels of target genes $T N F-\alpha, I L-16, T G F-B$, and $I L-10$ revealed a considerable down-regulation (Figure 2 ). There was a substantial difference between the treatments, with cassava peel notably different from the other treatments in terms of $T N F-\alpha$ and $I L-1 B$ expression.

When normalised against $\beta$-actin, TNF- $\alpha$, and IL-16 are down-regulated relative to the calibrator sample, but there is a statistically significant difference $(p<0.05)$ among the bioflocs treatment, but $I L-10$ and TGF- $B$ are up-regulated with no significant difference among the bioflocs treatment (Figure 3).

\section{Discussion}

The non-significant differences in fish growth performance in the treatment groups, Weight gain, SGR, and FCR, could indicate that the bioflocs system did no influence on fish development and that the feed was efficiently utilised by fish produced in the bioflocs system at a Carbon Nitrogen Ratio of 20. (Avnimelech, 2007). There is a sliver of evidence suggesting the biofloc helped to the fish's development and production, which contrasts with the findings of Azim \& Little (2008), who found that bioflocs had a low FCR in Oreochromis niloticus. Increased turbidity owing to bioflocs, which limits visibility and thus artificial feed intake, could be attributed to the increased $F C R$ and reduced weight gain of fish species in the $\mathrm{CP}+\mathrm{BFT}$, WO+BFT, and BW+BFT when compared to the control. When compared with the control, the survival rate of the fish in the bioflocs systems were considerably greater $(p<0.05)$. Several pathogenic species, such as bacteria, fungi, and viruses have been identified as major limiting factors in fish and other aquatic animals' growth. A. hydrophilia is the most prevalent and commonly seen bacterial disease in tropical regions, causing serious harm to fish output (Karunasagar et al., 1991). BFT has been demonstrated to boost fish immune responses, but just a few types of research have looked in the resistance of aquatic animals cultivated in bioflocs-based systems to infectious disease, with no promising results thus far. Bioflocs-based systems greatly boosted resistance of $L$. vannamei to infectious myonecrosis virus and $L$. rohita to A. hydrophila, according to Ekasari et al. (2014) and Ahmad et al. (2016). This is attributable to their better innate immune responses. Before the bacterial challenge test, there were no significant differences in

Table 4. Characterization of Fungi isolate in biofloc systems

\begin{tabular}{lcccc}
\hline Treatment & Control & Cassava peel & Tapioca & Wheat offal \\
\hline Trichoderma viride & + & + & + & - \\
Fusarium sp. & - & + & + & - \\
Aspergillus niger & + & - & + & + \\
Trichoderma sp. & - & - & - & - \\
Aspergillus flavus & - & - & - & - \\
Fusarium oxysporium & - & - & - & + \\
Penicillium chrysogenum & + & - & - \\
Rhizopus stolonifer & - & & + \\
\hline
\end{tabular}


haematological parameters across the treatments in this study. Although the WBC of the different treatments showed no significant difference to the control, a higher value of WBC was observed in the BFT compared to the control, which could be the result of the destruction of WBC during macrophagosis in the control group, the bioflocs group were able to release more antibody to counter the effect. Bioflocs have been shown to be an effective way of reducing $A$. hydrophila, a widespread disease-causing bacterium found all over the world, especially in intensive freshwater systems (Saavedra et al., 2004; Zmyslowska et al., 2009). Ulcers, depigmentation, fraying, and reddening of fins are all symptoms of $A$. hydrophila infections, which can be fatal to $C$. gariepinus and result in significant economic losses (FAO, 2016; Kusdarwati et al., 2017). As a result, BFT could be a good way to protect catfish from $A$. hydrophila infection during intensive culture.
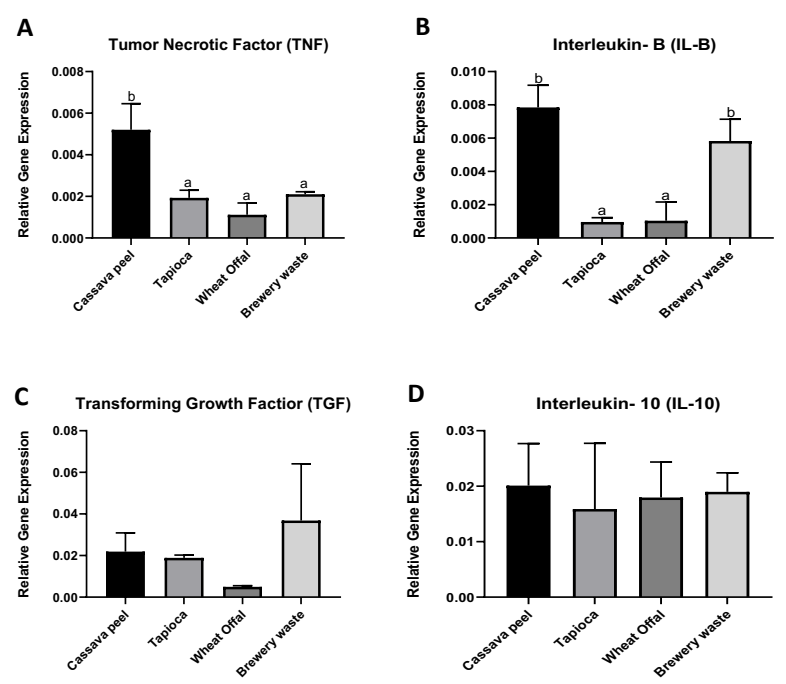

Figure 2. Mean fold change in gene expression + standard error in four treatment groups for four different genes A, B, C, $D$ relative to the calibrator sample normalized against $G A P D H$ $(p<0.05)$.

Microorganisms such as bacteria and protozoa produce microbial proteins in ponds under aerobic and anaerobic conditions by decomposing organic debris and uneaten feed. According to Reddy and Patrick (1975), the aerobic decomposition process is usually faster than the anaerobic decomposition process because the presence of oxygen speeds up the rate of breakdown. Natural production, nutrient cycling, water quality, and the nutrition of farmed animals are all influenced by microorganisms (Moriarty, 1997; Mclntosh et al., 2000). In many cases, the microorganisms identified as being involved in the above process are restricted. So yet, only about a quarter of naturally occurring bacteria have been isolated and characterised (Muyzer et al., 1993). The classification of the groups as microorganisms is common in most BFT culture investigations (Ballester et al., 2010; Ray et al., 2010; Loureiro et al., 2012; Emerenciano et al., 2013). As a result, the formation of a distinct, dominant, uniform, and diverse microbial community with traits including reproductive strategy, small size, short life cycle, and broad tolerance to environmental influences is postulated. These bacteria can also establish themselves as a result of system variables such as carbon supply, initial inoculum, and, as demonstrated in this study, the cultured species' behavior and nutritional habits.
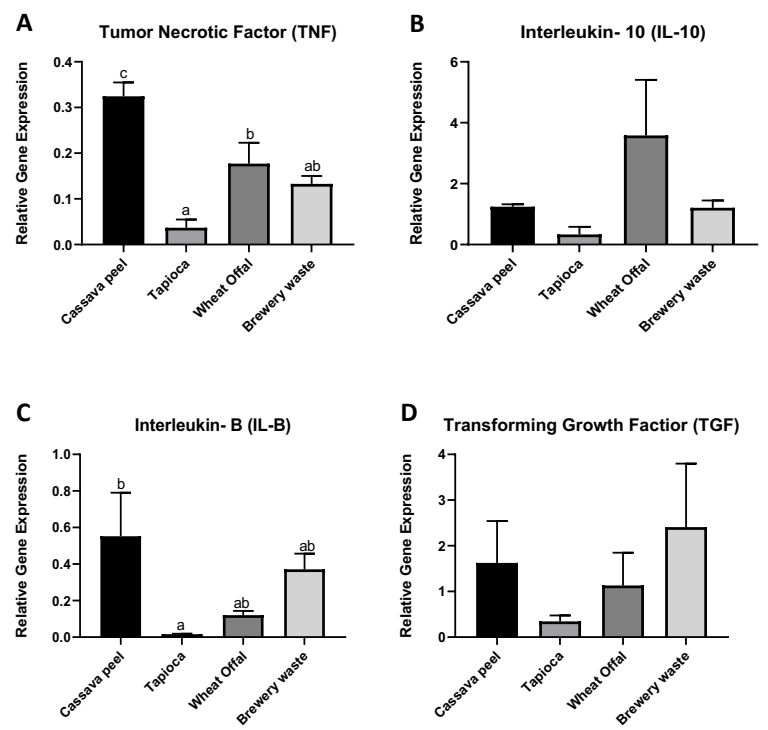

Figure 3. Mean fold change in gene expression + standard error in four treatment groups for four different genes A, B, C, $D$ relative to the calibrator sample normalized against Actin $(p<0.05)$.

The microbiota in the system has an impact on nutrient dynamics; these were characterised for Enterobacteriaceae, Bacillus, Coccus, and heterotrophic organisms, which agrees with the findings of MonroyDosta et al., (2013) who discovered heterotrophic bacteria such as Pseudomonas, Bacillus, Vibrios, Enterobacter, and Micrococcus in the microbial community connected with the bioflocs in tilapia culture. In farming settings, this species of bacteria promotes established channels for the elimination of hazardous nitrogen compounds. According to Ebeling et al. (2006), the main routes within the flow of nutrients in BFT culture systems are nitrogen elimination by photoautotrophic algae, nitrogen immobilisation by heterotrophic bacteria of the microbial protein biomass, and nitrogen chemo-autotrophic oxidation in nitrate by nitrifying bacteria. Depending on the type and intensity of the manufacturing system, the relative importance of each one varies. Although heterotrophic bacteria were encouraged to immobilise, the system was dominated by nitrifying bacteria in this study.

The importance of Bacillus colonies, which have probiotic properties, in the development of fish culture is underlined because these genera emit a wide range of exoenzymes and polymers that create a hostile environment for pathogenic bacteria (Monroy et al., 
2010). Although routes of nitrification and recycling of nitrogen compounds exist under the minimum requirements of nutrients and the management of water quality in optimal ranges for the cultivation of the species, the system is maintained by established bacterial communities (Ayazo-Gene et al., 2019). The results of this study show that the presence of specific microorganisms varied across treatments, and that a significant difference in CFU of total bacterial and SFU of total fungi could be attributed to differences in the composition of the carbon sources (simple and complex carbohydrate) used in the experiment, allowing us to conclude that the fungi and bacterial communities varied across all treatments. The current microbiota is linked to the system's dynamics, with a higher proportion of enterobacteria and heterotrophic bacteria. The immune system is divided into two parts: innate (non-specific) and adaptive (specific). Innate immunity serves as a barrier against infections, foreign substances, chemical agents, and environmental changes, and fish rely heavily on it. The innate immune system of fish is made up of several different components, each of which serves a specific purpose. Many research has been conducted to determine and understand the behavior of immune-related genes in both normal and pathologic states on Acipenser dabryanus (Dabry's sturgeon) (Zhang et al., 2018), on (Carassius auratus) (Qihecrucian carp) (Wang et al., 2013, 2016), on Ctenopharyngodon idella (grass carp) (Gou et al., 2018), on Pelteobagrus fulvidraco (yellow catfish) (Liu et al., 2016), on channel catfish (Prideon et al., 2013), and on Oncorhynchus mykiss (rainbow trout) (Yarahmadi et al., 2016). Inadequate research on $C$. gariepinus immune system is a key stumbling block to understanding immune system development, vaccine development, and immune stimulant evaluation. In addition, using marker assisted selection or selective breeding, bacterial resistance strains can be selected. There is still a lack of information about $C$. gariepinus immune-related genes, as well as evaluation of the immune response based on immune genes on the mRNA level following stress induction and bacterial infection. Due to the current state of $C$. gariepinus immune response, it is required to expand research on the expression of immune-related genes following a bacterial challenge. This paper reports on the expression of immune-related genes in the liver (a significant immunological organ in fish) of $C$. gariepinus maintained in bioflocs systems and challenged with $A$. hydrophilia, which will aid in a better understanding of the disease resistance mechanism.

When determining the biological significance of changing gene expression profiles, it's crucial to consider the amount of expression in comparison to the control (Gorgoglione et al., 2013) Relative quantification is a widely used approach for analysing gene expression, and as the name implies, it is an analysis based on the target gene's expression being normalised relative to the expression of a control gene (Kheirelseid et al.,
2010). Changes in cytokine gene expression were detected between treatments and between the reference genes employed (Table 5). TNF- $\alpha$ and IL-16 were observed in the liver to generate a statistically significant increase in the fold among the treatments. In the cascade signaling of pro-inflammatory genes, TNF- $\alpha$ is most commonly the first cytokine secreted, which eventually leads to the downstream of $I L-16$ and other chemokines. In parasite and bacterial infections, cytokines such as $I L-16$ and TNF- $\alpha$ are key and crucial mediators of pro-inflammatory responses, and they are frequently co-expressed with other macrophagederived inflammatory mediators such as $I L-16$. The target genes' fold changes in all treatments, adjusted against $G A P D H$, were significantly lower than in the calibrator sample (Untreated), which could be due to the presence of probiotic bacteria in the bioflocs culture medium. These findings matched those of Xiao et al. (2019), who looked into the effect of Clostridium butyricum (CB) diet on yellow catfish (Pelteobagrus fulvidraco).

Table 5. Mean fold change in gene expression for four different genes in $C$. gariepinus raised in biofloc systems

\begin{tabular}{|c|c|c|c|}
\hline Gene & Treatment & Beta-Actin & GAPDH \\
\hline \multirow[t]{5}{*}{ TGF-B } & Control & $1.05 \pm 0.74$ & $6.60 \pm 3.53^{*}$ \\
\hline & Cassava peel & $0.63 \pm 0.92$ & $1.02 \pm 0.43$ \\
\hline & Tapioca & $2.71 \pm 0.58$ & $0.87 \pm 0.07$ \\
\hline & Wheat offal & $1.24 \pm 1.07$ & $1.06 \pm 0.11$ \\
\hline & Brewery waste & $0.08 \pm 0.95$ & $1.60 \pm 0.84$ \\
\hline \multirow[t]{5}{*}{$T N F-\alpha$} & Control & $3.82 \pm 0.83^{* *}$ & $11.47 \pm 1.97^{* * *}$ \\
\hline & Cassava peel & $2.19 \pm 0.14^{*}$ & $3.84 \pm 0.35^{*}$ \\
\hline & Tapioca & $1.12 \pm 0.79$ & $2.42 \pm 0.28$ \\
\hline & Wheat offal & $1.27 \pm 0.38$ & $1.45 \pm 0.80$ \\
\hline & Brewery waste & $0.89 \pm 0.19$ & $2.57 \pm 0.08$ \\
\hline \multirow[t]{5}{*}{$I L-B$} & Control & $0.23 \pm 0.76$ & $7.42 \pm 3.55^{*}$ \\
\hline & Cassava peel & $1.24 \pm 0.67$ & $0.42 \pm 0.18$ \\
\hline & Tapioca & $6.22 \pm 0.23^{* * *}$ & $2.64 \pm 0.28$ \\
\hline & Wheat offal & $3.32 \pm 0.29^{* *}$ & $3.14 \pm 1.47$ \\
\hline & Brewery waste & $1.70 \pm 0.34$ & $0.02 \pm 0.23$ \\
\hline \multirow[t]{5}{*}{ IL-10 } & Control & $6.54 \pm 0.23^{* * *}$ & $14.19 \pm 2.57^{* * *}$ \\
\hline & Cassava peel & $6.85 \pm 0.10^{* * *}$ & $8.50 \pm 0.40^{* *}$ \\
\hline & Tapioca & $4.40 \pm 1.36^{* *}$ & $8.00 \pm 0.85^{* *}$ \\
\hline & Wheat offal & $8.16 \pm 0.81^{* * *}$ & $8.34 \pm 0.37^{* *}$ \\
\hline & Brewery waste & $6.78 \pm 0.30^{* * *}$ & $8.45 \pm 0.19^{* *}$ \\
\hline
\end{tabular}

The value for the negative control group for each gene and treatment is always 1 and is therefore not shown. Greater than two-fold increases or decreases in gene expression relative to the negative control appear in bold, and statistically significant changes are marked with asterisks: ${ }^{*}=p<0.05,{ }^{* *}=p<0.01,{ }^{* * *}=p<0.001$.

The results showed that downregulation of $I L-10$ expression in $C B$ treated fish could have resulted in the anti-inflammatory effect of the probiotic administered after bacterial challenge. Probiotics have been shown to be effective against bacterial pathogens in aquaculture species (Chinabut \& Puttinaowarat, 2005; Rendueles et al., 2012; Plaza-Diaz et al., 2014). The presence of this probiotic in the bioflocs culture system can increase the organism's tolerance to pathogenic invasion by inducing the secretion of anti-inflammatory cytokines such as IL-10 and TGF- $\beta$ as standardised 
against Actin relative to the calibrator sample, the fold change seen in this study was down-regulated (TNF- $\alpha$ and $(L-16)$, with the tapioca-based treatment being the most down-regulated among the treatments when compared to the control. This could explain why, in response to the inflammatory response, proinflammatory genes were activated more in the tapiocabased bioflocs than in the other treatments. Other immune-related signaling pathways and enzyme activity production are affected by these inflammatory substances. As a result, $I L-16$ and TNF- $\alpha$ are two major pro-inflammatory molecules that can trigger an inflammatory response by controlling the expression of other cytokines (Zhang et al., 2018). It's worth noting that the bioflocs culture technique drastically lowered $T N F-\alpha$ and $I L-1 B$ expression in this study.

The immune response genes TGF- $B$ and $I L-10$ in $C$. gariepinus were up-regulated in the bioflocs-based treatments, with the exception of the tapioca-based bioflocs system, which was down-regulated compared to a calibrator sample (Untreated). The up-regulation of these anti-inflammatory cytokines shows that the proinflammatory response began early in the challenge, since $I L-10$ was up-regulated in this study compared to the negative control. $I L-10$ regulates the immunological response of the fish by preventing macrophages from releasing pro-inflammatory cytokines such as $T N F-\alpha, I L-$ 2 , and $I L-3$. $T N F, I L-16$ may have been down-regulated because of this. The regulating effect of $I L-10$ on $I L-16$ expression has been found in Indian main carp (Catla catla) (Moore et al., 2001; Swain et al., 2011), IL-10 modulates inflammatory responses and potently inhibits the production of various cytokines including interleukin1 and TNF- $\alpha$.

TGF- $\beta$ is a pleiotropic cytokine that regulates inflammatory response onset and resolution. TGF- $B$ expression is up-regulated in rainbow trout when parasite pathogens are produced, according to research, and infection with IHNV on rainbow trout expression (Holland et al., 2003; Lindenstrom et al., 2004; Purcell et al., 2004). In this study, the bioflocs system increased TGF-B expression in all treatments when compared to the calibrator sample, indicating that the fish grown in the bioflocs system had a higher level of resistance. Although the fold change was normal in magnitude, it was statistically significant between the control and treatment groups.

\section{Conclusion}

Due to its numerous advantages, bioflocs technology is one of the most widely used advanced culture methods in shrimp and fish farming. It provides nourishment for the cultured animals and increases the farm's biosecurity while requiring little or no water exchange. This study and its findings have shed light on the impact of bioflocs consumption on $C$. gariepinus immunological performance and gene expression. This provides important information about bioflocs supplementation in feed and its development in culture ponds for the maintenance of optimal water quality parameters, growth performance, and immune gene regulation in C. gariepinus grow-out culture systems.

\section{Funding Information}

The research work was supported by the Tertiary Education TrustFund (TETFUND) [grant numbers VCPU/TETFund/155C.

\section{Author Contributions}

Conceptualization: OMP, Data Curation: AMO, STT, Formal Analysis: AMO, Funding Acquisition: AMO, STT, OMP, Investigation: AMO, STT, Methodology: OMP, AMO, Project Administration: AMO, STT, Resources: AMO, STT, OMP, Supervision: OMP, Visualization: OMP, Writing -original draft: AMO, Writing -review and editing: AMO, STT, OMP.

\section{Acknowledgments}

The authors are grateful to the Department of Fisheries and Aquaculture Technology, Department of Microbiology, Federal University of Technology, Akure, and National Center for Genetic Resources and Biotechnology (NACGRAB), Ibadan, for their financial, technical, and logistical support during sampling. We are also grateful to Dr. Oduoye M, and Mr Fred Ali their assistance with field and laboratory work.

\section{References}

Abbott, W. S. (1925) A method of computing the effectiveness of an insecticide, Journal of Economic Entomology, 18, 265-267.

Adebayo, O. O., \& Daramola, A. O. (2013). Economic analysis of catfish (Clarias gariepius) production in Ibadan metropolis. Discourse Journal of Agriculture and food sciences, 1(7), 128 - 134

Ahmad, I., Verma, A. K., Rani, A. M. B., Rathore, G., Saharan, N. \& Gora, A. H. (2016). Growth, non-specific immunity and disease resistance of Labeo rohita against Aeromonas hydrophila in biofloc systems using different carbon sources. Aquaculture, 457, 61-67. https://doi: 10.1016/j.aquaculture.2016.02.011.

Amend, D. F. (1981). Potency testing of fish vaccines. Fish biologics: serodiagnostics and vaccines, 447-454.

APHA (1998). Standard method for the examination of water and wastewater. 20th edition, American Public Health Association, American Waters Works Association and Water Environmental Federation, Washington DC.

Avnimelech, Y. (1999). Carbon and nitrogen ratio as a control element in aquaculture systems. Aquaculture, 176, 227-235. $\quad$ https://doi.org/10.1016/S00448486(99)00085-X.

Ayazo-Genes, J., Pertúz-Buelvas, V., Jiménez-Velásquez, C., Espinosa-Araujo, J., Atencio-García, V., \& PrietoGuevara, M. (2019). Describing the planktonic and 
bacterial communities associated with bocachico Prochilodus magdalenae fish culture with biofloc technology. Revista MVZ Córdoba, 24(2), 7209-7217. https://doi.org/10.21897/rmvz.1648.

Azim, M. E. \& Little, D. C., (2008). The Biofloc Technology (BFT) in indoor tanks: Water quality, biofloc composition and growth and welfare of Nile tilapia (Oreochromis niloticus). Aquaculture, 283, 29-35. https://doi.org/10.1016/j.aquaculture.2008.06.036.

Ballester, E., Abreu, P., Cavalli, R., Emerenciano, M., Abreu, L., \& Wasielesky, W. (2010). Effect of practical diets with different protein levels on the performance of Farfantepenaeus paulensis juveniles nursed in a zero-exchange suspended microbial flocs intensive system. Aquaculture Nutrition, 16, 163-172. http://dx.doi.org/10.1111/j.13652095.2009.00648.x.

Chinabut, S., \& Puttinaowarat, S. (2005). The choice of disease control strategies to secure international market access for aquaculture products. Developments in Biologicals, 121, 255-261.

Crab, R., (2010). Bioflocs technology: an integrated system for the removal of nutrients and simultaneous production of feed in aquaculture. PhD thesis, Ghent University. $178 \mathrm{pp}$.

Crab, R., Avnimelech, Y., Defoirdt, T., Bossier, P., \& Verstraete, W., (2007). Nitrogen removal techniques in aquaculture for a sustainable production. Aquaculture, 270, 1-14. http://dx.doi.org/10.1016/i.aquaculture.2007.05.00 6

Crab, R., Lambert, A., Defoirdt, T., Bossier, P., \& Verstraete, W., (2010). Bioflocs protect gnotobiotic brine shrimp (Artemia franciscana) from pathogenic Vibrio harveyi. Journal of Applied Microbiology, 109, 16431649. $\quad$ https://doi.org/10.1111/j.13652672.2010.04791.x

Ebeling, J. M., Timmons, M. B., \& Bisogni, J. J. (2006). Engineering analysis of the stoichiometry of photoautotrophic, autotrophic, and heterotrophic removal of ammonia-nitrogen in aquaculture systems. Aquaculture, 257(1-4), 346-358. https://doi.org/10.1016/j.aquaculture.2006.03.019

Ekasari, J., Azhar, M. H., Surawidjaja, E. H., Nuryati, S., De Schryver, P., \& Bossier, P. (2014). Immune response and disease resistance of shrimp fed biofloc grown on different carbon sources. Fish Shellfish Immunology, 41, 332-339. https://doi.org L10.1016/i.fsi.2014.09.004.

Emerenciano, M., Gaxiola, G., \& Cuzon, G. (2013) Biofloc technology (BFT): a review for aquaculture application and animal food industry. In: Biomass now - cultivation and utilization (ed. by M.D. Matovic). InTech, Queen's University, Belfast, pp 301-328

Food and Agriculture Organization (FAO) (2016). Cultured Aquatic Species Information Programme Penaeus Monodon (Fabricius, 1798). Presence of giant tiger shrimp Penaeus monodon Fabricius, 1798 on the Mexican coast of the Gulf of Mexico. Available from: https://www.researchgate.net/publication/259390 $\underline{783}$ Presence of giant tiger shrimp Penaeus monodon Fabricius 1798 on the Mexican coast of the Gulf of Mexico [accessed Oct 19 2021].
Gorgoglione, B., Wang, T., Secombes, C. J., \& Holland, J. W. (2013). Immune gene expression profiling of proliferative kidney disease in rainbow trout Oncorhynchus mykiss reveals a dominance of antiinflammatory, antibody and $\mathrm{T}$ helper cell- like activities. Veterinary Research, 44(1), 1-16. https://doi.org/10.1186/1297-9716-44-55.

Gou, C., Wang, J., Wang, Y., Dong, W., Shan, X., Lou, Y., \& Gao, Y. (2018). Hericium caput-medusae (Bull.:Fr.) Pers. polysaccharide enhance innate immune response, immune-related genes expression and disease resistance against Aeromonas hydrophila in grass carp (Ctenopharyngodon idella). Fish Shellfish Immunology, 72, 604-610. https://doi.org/ 10.1016/j.fsi.2017.11.027.

Hargreaves, J. A. (2006). Photosynthetic suspended-growth systems in aquaculture. Aquaculture Engineering, 34, 344-363. https://doi.org/10.1016/j.aquaeng.2005.08.009.

Holland, J. W., Gould, C. R., Jones, C. S., Noble, L. R., \& Secombes, C. J. (2003). The expression of immuneregulatory genes in rainbow trout, Oncorhynchus mykiss, during a natural outbreak of proliferative kidney disease (PKD). Parasitology, 126, S95e102. https://doi.org/10.1017/s0031182003003767.

Ita, E. O. (1980). The review of recent advances in warm water aquaculture research and proposed experimental design for maximizing fish production in Nigerian fish pond. Lake kainji research institute, 1-59.

Janda, J. M., \& Abbott, S. L. (2010). The Genus Aeromonas: Taxonomy, Pathogenicity, and Infection. Clinical Microbiology Reviews, 23(1), 35-73. https://doi.org/10.1128/cmr.00039-09.

Joseph, S. W., \& Carnahan, A. (1994). The isolation, identification, and systematics of the motile Aeromonas species. Annual Review of Fish Diseases. 4, 315-343. https://doi.org/10.1016/09598030(94)90033-7.

Karunasagar, I., Rosalind, G. M., \& Karunasagar, I. (1991). Immunological response of the Indian major carps to Aeromonas hydrophila vaccine. Journal of Fish Diseases, 14, 413-417. https://doi.org/10.1111/j.13652761.1991.tb00841.x.

Kheirelseid, E. A, Chang, K. H., Newell, J., Kerin, M. J., \& Miller, N. (2010). Identification of endogenous control genes for normalisation of real-time quantitative PCR data in colorectal cancer. BMC Molecular Biology, 11(1), 1-13. https://doi.org/10.1186/14712199-11-12.

Kusdarwati, R., Kurniawan, H., \& Prayogi, Y. T. (2017, February). Isolation and identification of Aeromonas hydrophila and Saprolegnia sp. on catfish (Clarias gariepinus) in floating cages in Bozem Moro Krembangan Surabaya. In IOP Conference Series: Earth and Environmental Science, 55(1), 012038. IOP Publishing.

Lindenstrøm, T., Secombes, C. J., \& Buchmann K. (2004). Expression of immune response genes in rainbow trout skin induced by Gyrodactylus derjavini infections. Vetenary Immunology \& Immunopathology, 97(3-4), 137-48. https://doi:10.1016/i.vetimm.2003.08.016.

Liu, Q. N., Xin, Z. Z., Zhang, D. Z., Jiang, S. H., Chai, X. Y., Li, C. F., Zhou, C. L., \& Tang, B. P. (2016). Molecular 
identification and expression analysis of a goosetype lysozyme (LysG) gene in yellow catfish Pelteobagrus fulvidraco. Fish and Shellfish Immunology, 58, 423-428. https://doi.org/10.1016/j.fsi.2016.09.034.

Loureiro, K., Wilson, W., \& Abreu, P. (2012). Use of protozoa, rotifers and nematodes as live feed for shrimp cultured in the BFT system. Atlântica Rio Grande, 34(1), 5-12.

McIntosh, D., Samocha, T. M., Jones, E. R., Lawrence, A. L., McKee, D. A., Horowitz, S., \& Horowitz, A. (2000). The effect of a bacterial supplement on the highdensity culturing of Litopenaeus vannamei with low protein diet in outdoor tank system and no water exchange. Aquacultural Engineering, 21, 215-227. https://doi.org/10.1016/S0144-8609(99)00030-8.

Milstein, A., Avnimelech, Y., Zoran, M., \& Joseph, D. (2001). Growth performance of hybrid bass and hybrid tilapia in conventional and active suspension intensive ponds. Isreali Journal of AquacultureBamidgeh, 53, 147-157. http://hdl.handle.net/10524/19037.

Monroy, D., Castro, B., Fernández, P., \& Mayorga, R. (2010). Inhibition of Aeromonas hydrophila by probiotic strains isolated from the digestive tract of Pterophyllum scalare. Revista Mexicana Ingenieria Química, 9(1), 37-42.

Monroy-Dosta, M., De Lara-Andrade, R., Castro-Mejia, J., Castro-Mejia, G., Coelho-Emerenciano, M. (2013). Composición y abundancia de comunidades microbianas asociadas al biofloc en un cultivo de tilapia. Revista de biología marina y oceanografía, 48(3), 511-520. http://dx.doi.org/10.4067/S071819572013000300009

Moore, K. W., de Waal Malefyt, R., Coffman, R. I., O'Garra, A. (2001). Interleukin 10 and interleukin 10 receptor. Annual Review of Immunology, 19, 683-765. https://doi.org/10.1146/annurev.immunol.19.1.683

Moriarty, D. J. W. (1997). The role of microorganisms in aquaculture ponds. Aquaculture, 151, 333-349. https://doi.org/10.1016/S0044-8486(96)01487-1.

Muyzer, G., De Waal, E. C., \& Uitterlinden, A. (1993). Profiling of complex microbial populations by denaturing gradient gel electrophoresis analysis of polymerase chain reaction-amplified genes coding for $16 \mathrm{~S}$ rRNA. Applied and Environmental Microbiology, 59(3), 695-700. https://doi.org/10.1128/aem.59.3.695-700.1993

Plaza-Diaz, J., Gomez-Llorente, C., Fontana, L., \& Gil, A. (2014). Modulation of immunity and inflammatory gene expression in the gut, inflammatory diseases of the gut and in the liver byprobiotics. World Journal of Gastroenterology, 20(42), 15632-15649. https://dx.doi.org/10.3748\%2Fwig.v20.i42.15632.

Pridgeon, J. W., Klesius, P. H., Dominowski, P. J., Yancey, R. J., \& Kievit, M. S. (2013). Chicken-type lysozyme in channel catfish: Expression analysis, lysozyme activity, and efficacy as immunostimulant against Aeromonas hydrophila infection. Fish \& Shellfish Immunology, 35(3), 680-688. https://doi.org/10.1016/i.fsi.2013.05.018.

Purcell, M. K., Kurath, G., Garver, K. A., Herwig, R. P. \& Winton, J. R. (2004). Quantitative expression profiling of immune response genes in rainbow trout following infectious haematopoietic necrosis virus (IHNV) infection or DNA vaccination. Fish Shellfish Immunology, 17, 447- 462. https://doi: 10.1016/i.fsi.2004.04.017. PMID: 15313511.

Ray, A. J., Seaborn, G., Leffler, J. W., Wilde, S.B., Lawson, A., \& Browdy, C. L. (2010). Characterization of microbial communities in minimal-exchange, intensive aquaculture systems and the effects of suspended solids management. Aquaculture 310, 130-138. https://doi.org/10.1016/j.aquaculture.2010.10.019.

Reddy, K. R., \& Patrick, J. W. H. (1975). Effect of alternate aerobic and anaerobic conditions on redox potential, organic matter decomposition and nitrogen loss in a flooded soil. Soil Biology and Biochemistry, 7, 87-94. https://doi.org/10.1016/0038-0717(75)90004-8.

Rendueles, O., Ferri'eres, L., \& Fr'etaud, M. (2012). A new zebrafish model of oro-intestinal pathogen colonization reveals a key role for adhesion in protection by probiotic bacterial. PLoS Pathogens, $8(7)$, e1002815. https://doi.org/10.1371/journal.ppat.1002815.

Saavedra, M. J., Guedes-Novais, S., Alves, A., Rema, P., Tacao, M., Correia, A., \& Martinez-Murcia, A., (2004). Resistance to B-Lactam antibiotics in Aeromonas hydrophila isolated from rainbow trout (Oncorhynchus mykiss). International Microbiology, 7, 201-211.

Sabur, M. A. (2006). Studies on the ecology of the pathogenic bacteria Aeromonas hydrophila in indigenous and exotic carps under polyculture condition. $A P h$. D. Dissertation. Department of Aquaculture, Bangladesh Agricultural University, Mymensingh Bangladesh, 136.

Svobodova, Z., Pravda, D., \& Palackova, J. (1991). Unified methods of haematological examination of fish. Research Institute of fish culture and hydrobiology.

Swain, B., Samanta, M., Basu, M., Panda, P., Sahoo, B. R., \& Maiti, N. K. (2011). Molecular characterization, inductive expression and mechanism of interleukin 10 gene induction in indian major carp Catla catla. Aquaculture Research, 43, 897-907, https://doi.org/10.1111/j.1365-2109.2011.02904.x.

Ture, M., Ozcelep, T., Akbulut, B., \& Kutlu, I. (2018). Disease of Russian sturgeon (Acipenser gueldenstaedtii) caused by Aeromonas sp. Genetics of Aquatic Organisms, 2(2), 43-47. https://doi.org/10.4194/2459-1831-v2 203

Wang, M., Zhao, X., Kong, X., Wang, L., Jiao, D., \& Zhang, H. (2016). Molecular characterization and expressing analysis of the c-type and g-type lysozymes in Qihecrucian carp Carassius auratus. Fish and Shellfish Immunology, 52, 210-220. https://doi.org/10.1016/j.aqrep.2019.100198.

Wang, R., Feng, J., Li, C., Liu, S., Zhang, Y., \& Liu, Z. (2013). Four lysozymes (one c-type and three g-type) in catfish are drastically but differentially induced after bacterial infection. Fish Shellfish and Immunology, 35, https://doi.org/10.1016/j.fsi.2013.04.014.

Xiao, Y., Yu, L., Gui, G., Gong, Y., Wen, X., Xia, W., Yang, H., \& Zhang, L. (2019). Molecular cloning and expression analysis of interleukin- 8 and -10 in yellow catfish and in response to bacterial pathogen infection. Biomed Research International, 6, 1-9 http://dx.doi.org/10.1155/2019/9617659. 
Xie, B., \& Yu, K. J. (2007). Shrimp farming in China: operating characteristics, environmental impact and perspectives. Ocean and Coastal Management, 50, 538-550.

http://dx.doi.org/10.1016/j.ocecoaman.2007.02.00 6.

Xu, W. J., \& Pan, L. Q. (2013). Enhancement of immune response and antioxidant status of Litopenaeus vannamei juvenile in biofloc-based culture tanks manipulating high $\mathrm{C} / \mathrm{N}$ ratio of feed input. Aquaculture, 412, 117-124. https://doi.org/10.1016/j.aquaculture.2013.07.017.

Yarahmadi, P., Miandare, H. K., Fayaz, S., \& Caipang, C. M. A. (2016). Increased stocking density causes changes in expression of selected stress- and immune-related genes, humoral innate immune parameters and stress responses of rainbow trout Oncorhynchus mykiss. Fish and Shellfish Immunology, 48, 43-53. https://doi.org/10.1016/j.fsi.2015.11.007.

Zhang, S., Xu, Q., Boscari, E., Du, H., Qi, Z., Li, Y., Huang, J., Di, J., Yue, H., Li, C., Congiu L, \& Wei, Q. (2018). Characterization and expression analysis of g- and ctype lysozymes in Dabry's sturgeon Acipenser dabryanus. Fish and Shellfish Immunology, 76, 260265. https://doi.org/10.1016/j.fsi.2018.03.006.

Zmyslowska, I., Korzekwa, K., \& Szarek, J. (2009). Aeromonas hydrophila in fish aquaculture. Journal of Comparative Pathology, 141, 313 http://dx.doi.org/10.1016/i.jcpa.2009.08.142. 